\title{
THE VIOLENCE BASED ON RELIGION AS A FACTOR OF THE DISTRIBUTION OF THE WORLD POLITICAL PROCESS
}

\author{
IHOR MYKHALSKYI
}

\begin{abstract}
The article deals with the role of political violence in the modern world through the prism of exacerbation of cultural-religious contradictions. Based on the analysis of statistical data, the tendencies of the spread of confrontation on religious grounds have been revealed, such as discrimination and impairment of the rights of religious communities, ethnic-confessional conflicts, and the spread of transnational religious terrorism. It is concluded that the politicization of religions is a significant factor of social and political destabilization both at the regional and global levels.
\end{abstract}

Keywords: political violence, political conflict, religion, civilization, ethnoconfessional contradictions, Islamism, transnational terrorism.

\section{INTRODUCTION}

One of the main destructive trends of the modern world is the general destabilization of the sociopolitical space. This process is conditioned by a whole range of factors, among which - the aggravation of global problems: ecological, demographic, resource, energy, cultural and civilization, etc. In the first place, destabilization is realized in the rise of the level of political violence. Existing mechanisms for securing peace and security, formed within the framework of the Yalta-Potsdam system of international relations, proved to be ineffective in the new conditions that arose after the collapse of the bipolar order. Consequently, efforts to establish a collective security system on a global scale, the primary role of which is played by the United Nations, have failed. This is clearly indicated by the rapid increase of the number of political conflicts in many regions, the evolution and improvement of the forms of confrontation, the build-up of armaments, and the increase of the human casualties within the civilian population against the background of the inactivity of international structures.

\section{ANALYSIS AND DiscusSiON}

An important measure of the intensification of violence around the world is the intensification of the confrontation on the religious-confessional foundation. The leading role of the religious factor in inter-civilizational relations and conflicts was emphasized by S. Huntington. The scientist noted that "of all the objective elements that determine civilization, the most important, however, is religion ... The 
main civilizations in human history were largely identified with the great religions of the world, and people of common ethnicity and common language, but different religions, can lead a bloody war ..." [8, p. 49].

The analysis of the dynamics of the current confrontation shows that zones of permanent instability are formed in almost all regions of the world, which cover rather wide locations. Such zones exist in Africa, the Middle East, South and South-East Asia, and Latin America. The main leading actors in these processes is the religious communities and organizations, among which a special role belongs to Islamist groups and states. An important factor in the activation of radical religious movements is globalization, which by compressing the socio-political space through the development of communications, informatization, the formation of a single market, creates transparent borders, brings together and intensifies contacts between different ethno-national, religious, and cultural communities.

The significant measure of politicization of religions and general destabilization is the intensification of persecution or discrimination on religious grounds. According to a study by the "Pew Research Center", reflected in the "Trends in Global Restrictions on Religion" report, in 2014, 16 out of the 198 countries had "too high" levels of religion constraints. These countries were China, Egypt, Uzbekistan, Turkey, Indonesia, Iran, Syria, Saudi Arabia, Kazakhstan, Azerbaijan, Turkmenistan, Laos, Malaysia, Maldives, Russia, Tajikistan. The number of countries with a high level of religious restrictions has decreased from 37 (in 2013) to 32 (in 2014), and with moderate restrictions, on the contrary, increased from 45 to 57 [11, p. 13].

Regarding the dynamics of direct religious violence, the analysis shows that the most intense religious violence in 2014 was illustrative of 11 countries (against 17 countries in 2013), namely: Israel and the Palestinian territories, Iraq, Syria, Yemen, Pakistan, Sri Lanka, India, Afghanistan, Lebanon, Nigeria. Among macroregions, the worst indicators of religious tolerance are demonstrated by the Middle East and the Maghreb, where the average index of religious restrictions is 5,4, while in the AsiaPacific region it is 3,7, Europe - 2,5, sub-Saharan Africa - 1,6, and America - 1,6 [11, p. 14, 22].

The most persecuted religious communities were Christians and Muslims as the most numerous, while in the second place were Hindus and Jews. In particular, Christians were persecuted in 108 countries (in 102 countries - in 2013), Muslims - in 100 countries (in 99 countries - in 2013). Antisemitic spirits are growing. Jews, which make up $0.2 \%$ of the world's population, have been subjected to direct violence or discrimination in 81 countries (in $2013-77,2012$ - 71 countries). Also, the level of tolerance to the Indians, which were pursued in 14 countries (in 2013 - 9 countries), has grown. Facts of Buddhist discrimination were recorded in 12 states. The total number of countries where the facts of religious persecution were recorded was 159 [11, p. 20].

According to studies of the Heidelberg Institute for the Study of International Conflicts, systemic and ideological contradictions, including religious ones, are the most widespread reason for conflicts in the modern world. They give way to such acute factors as the struggle for resources or power, ethnonational contradictions, secession, interstate strife, territorial claims. Among the total number of conflicts in 2017 (385, of which 222 were violent ones), 148 contradictions as the main or secondary factor had the oppositions on the systemic and ideological basis. In addition, systemic-ideological conflicts are often characterized by high intensity, that is, they tend to grow into war [1, p. 16].

S. Huntington considered the dominant form of violence in the modern world the conflicts with the participation of Muslim adherents, linking it with the strengthening and articulation of the religious identification of Muslims. According to him, "the Islamic revival is in general a response to modernization and globalization, and in most cases this answer is quite constructive", since the very purpose of Islamist organizations is to meet the social, economic, humanitarian, spiritual and cultural needs of the Muslim communities, to uphold their interests before ineffective, corrupt or repressive governments [7].

In addition, the scientist calls the factors of activism of Islamism: the desire to resist the culturalinformational and economic expansion of the West; the influence of structural and socio-political features of the traditional patterns typical of most Muslim societies, namely tribal, religious, ethnic, cultural differences; rivalry for the influence of various doctrines within Islam itself (first of all Sunni 
and Shiite); a demographic surge that has led to a sharp increase in the number of young people, especially young men who are replenishing the ranks of radical groups.

Radical fundamentalist circles perceive an interpenetration of cultures as a threat to their own identity, responding to this aggravation of aggression, activation of terrorist activity. The representatives of traditional and orthodox societies associate globalization and the universalization of values based on a liberal world outlook with moral degradation, the loss of its own system of values and cultural models, the decline of the role of religion, the collapse of communities, the departure of sources of Islam, the "offense" of Muslims from Western society, economic crisis. There is also growing tension within the Muslim world itself, due to the imbalance in socio-economic development, the confrontation between the secular and fundamentalist outlook, the attempts to reconstruct the traditional order inherent in early Islam, and the contradictions between representatives of different areas of Islam, in particular Shiites and Sunnis.

In this case, modern science determines the trend of "politicizing Islam", and Islam becomes a sign of political and ideological doctrine. Islamic and Islamist organizations are actively involved in politics and are a powerful force that affects both internal political processes within the states and geopolitical transformations.

Consequently, in the context of the destabilization of the socio-political environment, Islamism, as a radical variant of Islam, is a powerful conflict-making factor. Unlike traditional Islam, it has a number of peculiarities. In particular, A. Petrukhina defines the following specific features: an appeal to the restoration of primary Islamic values; traditionalism and statism, expressed in the offer of "the ideal version of society ... and of a state based on Sharia law, social justice, with a strong ruler", which essentially means the introduction of the theocratic regime; propagating the idea of jihad and justifying terror by extremist forces [9, p. 103].

The most fierce struggle with Islamist groups or ethnoconfessional communities is currently taking place in the Central African Republic, Nigeria, Cameroon, Chad and Niger, Somalia and Kenya, Sudan (Sub-Sahara Region); Afghanistan, Syria and Iraq, Libya, Yemen (Middle East and Maghreb); Myanmar and the Philippines (Asia-Pacific) [1, p. 13].

In particular, in the Central African Republic, the confrontation is between Christian and Muslim communities, the first of which is represented by the pro-government forces united into the organization of Anti-Balaka, the second - the Muslim groups "Seleka". Nigeria, Cameroon, Chad and Niger are covered by the war with the terrorist Islamist organization Boko Haram, known for mass killings and kidnappings. In Somalia, with the participation of Kenya, there is a confrontation with another radical Islamist group Al-Shabaab. High-intensity violence takes place in Sudan, where the rivalry between the Muslim Arab forces and the indigenous Negro people continues within the Darfur conflict.

There are several "hot spots" for a long time in the Middle East. The civil war in Afghanistan, the main actor of which is the Islamist Taliban movement, does not subsist. The struggle with the "Islamic State" continues in the context of civil wars in Syria and Iraq. In Yemen, there is a Shiite-Sunni internationalized conflict involving Saudi Arabia. There is a high level of tension between Israel and the Palestinian territories, where the interests of the latter are the radical Islamist movement of Hamas and other Salafist groups. Large-scale collective violence takes place in Myanmar, where the Buddhist majority discriminates and persecutes Muslims of the Rohingya people, who constitute an ethnic minority. In the Philippines, Islamists "Abu Sayyaf" and "Maute" are struggling with government forces.

We also should pay attention on the current conflict in Myanmar, which has recently become a sign of genocide. Violence here has several dimensions - ethnoconfessional, economic, demographic. The state of Rakhine, mostly populated by Muslims of the Rohingya people, is the poorest in the country. Of the over one million Burmese rochindia, about 800,000 live in the state of Rakhine. The main part of the population here is below the poverty line. In addition, a frankly discriminatory policy is being introduced at the state level regarding the Muslim minority. This is reflected in the restriction of freedom of movement, discriminatory barriers to access to education and workplaces, the refusal of 
Rochinga in the citizenship of the state. Rochinga is the bearer of its own - not only a confessional, but also ethno-national identity, different from the identity of most of the Buddhist population of Myanmar. Due to this they consider themselves and the state of the country as the part of Bangladesh and Bengal culture with historical, cultural, linguistic perspectives. Consequently, the conflict has a significant historical background and can be considered through the prism of the cultural and civilization context. The escalation of the conflict began in 2012, when discrimination has intensified and cases of direct physical violence against rochinga by ultranationalist Buddhist extremists and the forces of the official government have become more frequent. The Buddhist majority of Myanmar's population demonstrates an extremely intolerant attitude towards the Muslim minority of the Rochinga, considering them as a threat to their own identity, economic prosperity, and competitors in job placement.

The problem of restriction of movement is especially acute. As stated in the official report of the Office of the United Nations High Commissioner for Human Rights, "the Rohingya face severe restrictions on their freedom of movement. In nRS, they require official authorization to move between, and often within, townships (for example, a village departure certificate is required to stay overnight in another village.). The procedures to secure travel are onerous and time-consuming, and failure to comply with requirements can result in arrest and prosecution. Restrictions routinely lead to extortion and harassment by law enforcement and public officials. Since the outbreak of violence in Rakhine in June 2012, a curfew was imposed in nRS, which offers broad discretionary powers to the authorities, including the case of limitations on assembly and prohibiting movement between dusk and dawn. This curfew remains in place, having been extended in the wake of the 9 October events referred to below" [2, p. 6].

Thus, it is easier for the Muslim population to cross the border with Bangladesh than to move within its own country. However, neighboring Bangladesh refuses rochinga asylum and does not accept them as refugees on their territory. Despite this, about 66 thousand people illegally crossed the border of a neighboring country. The result of this discriminatory policy is that 22,000 people are internally displaced persons, and in aggregate, almost 90,000 people have been affected by external or cross-border displacement. In addition, hundreds of people are complaining about direct violence by ultra-nationalists or representatives of power structures. Observers record numerous cases of murders, mutilations, beatings, rapes (including children), the destruction of property or sources of food [2, p. 67, 9-10].

An important indicator of the spread of violence on religious grounds is the activation of transnational terrorist organizations, the absolute majority of which represent the fundamentalist Islamist religious doctrine. The most active radical extremist groups today include the Islamic State, AlQaeda, Boko Haram, Taliban, Hamas, Hizballah, Muslim Brotherhood, the Union of Islamic Jihad, Palestine Islamic Jihad and so on. Such organizations are actors of socio-political destabilization both at the regional and international levels. The network structure and powerful funding flows allow them to carry out their devastating activities not only in countries that are in or out of their direct influence, but also in remote, stable regions, in particular, Europe.

Mortality from terrorism in recent years is estimated by tens of thousands of victims. According to "Global Terrorism Index 2017", in 2016 25,673 people were killed by terrorists. For many years, a number of Muslim countries, such as Afghanistan, Nigeria, Syria, Pakistan and Iraq, have been leading the terrorist threat, where about three quarters of all deaths by terrorists take place. In these countries the largest terrorist organizations of the day are: in Nigeria and its neighboring countries - Boko Haram, in Afghanistan and Pakistan - the Taliban, in Iraq and Syria - the Islamic State. Since 2002 in eight of the nine regions of the world (except North America) there is an increase in the level of terrorism, and this process is particularly intensive in the countries of the Middle East [5, p. 4].

One of the most active terrorist organizations whose activities are of a regional scale are Boko Haram, who swore allegiance to the "Islamic State". The group defends the most radical fundamentalist stance, opposed to Western education, lifestyle and world outlook. Activation of the group's activities took place in 2010 after the death of leader Mohammed Yusuf. The new leader, 
Abubakar Shekau, proclaimed jihad against the Nigerian authorities and the West. Since then, its terrorist activity has intensified. In 2014, the number of victims of the organization exceeded 6000 people. In general, more than 20,000 people were killed in the fighting between terrorists and Nigerian forces, about 2.6 million became internally displaced persons or migrants. However, due to the combined efforts of the governments of Nigeria, Cameroon, Niger and Chad, terrorist violence has been substantially limited. And already in 2016, the number of victims of the "Boko Haram" fell to 1079 people who died as a result of 192 attacks (against 454 attacks in 2014) [3, p. 4; 5, p. 74; 10].

The activity of terrorists in Afghanistan, by contrast, is increasing. The Taliban movement, which arose in 1994, uniting Mujahideen groups and Pashtun tribes, has been struggling with the government and international forces (NATO) since 1996 to restore control over the country. Today, the Taliban controls about $11 \%$ of the territory and is the main subject of the civil war in Afghanistan. The victims of the Taliban in 2016 were 3,586 people killed as a result of 848 terrorist attacks. The controversy, which has been around for almost 40 years, is a source of persistent instability in the region and affects neighboring territories, in particular Pakistan. The Taliban and Al Qaeda branches in Pakistan control the border area of Waziristan, that is why violence spreads across the country. Thus, the total number of victims of the terrorist attacks in Pakistan during the fifteen years (2000-2015 gg.) reached 14953 people $[4$, p. 28; 5, p. 74].

The most widespread network of cells is Al Qaeda, which carries out terrorist attacks in a number of African, Middle Eastern and other regions (Algeria, Bangladesh, Burkina Faso, Côte d'Ivoire, Kenya, Mali, Nigeria, Pakistan, Somalia, Syria, etc.). The organization has a large number of affiliates in many countries around the world. The most famous divisions in its structure are Al Qaeda on the Arabian Peninsula, Al Qaeda in Iraq, Al Qaeda in the Islamic Maghreb, Al Qaeda in the Indian Subcontinent. In 2016, this terrorist organization killed 1349 people by 539 terrorist attacks [5, p. 75].

Al Qaida, through its affiliated structures, is involved in many regional and local conflicts, especially in those regions where its influence extends. For example, Al Qaeda in the Islamic Maghreb has played one of the main roles during the Tuarez uprising (2012-2013), and also plays in the current confrontation between the government and the Islamist factions in Mali. The Tuarez uprising began as a typical separatist conflict between the official government and the Tuareg tribes in northern Mali, aimed at proclaiming the independence of the region of Azawad, a place of compact residence of the Tuaregs. Islamists, including Al Qaeda, initially being on the side of the rebels, after capturing Azavade, intercepted the initiative and proclaimed in the region their own rules, based on the Shari'a system. After the intervention of the French forces, the resistance was suppressed, but the conflict with the participation of Islamists continues, and a tense situation and a high level of political violence remains in the country. Islamist forces continue partisan, terrorist struggle and sabotage against the government.

One of the youngest terrorist multinational organizations of the present day is the "Islamic State" (according to various sources, it appeared in 2004 or 2006). The group has rapidly strengthened its position and in the short term turned into the most deadly organization of the world. "The Islamic State" is one of the main actors in the Syrian and Iraqi conflicts, which entered into confrontation with both the government and the opposition. The group is one of the main Salafist forces fighting both secular orders of the western model and the Shiite branch of Islam. In particular, the Salafist-Shiite opposition is one of the main dimensions of the struggle of the "Islamic State" in Iraq and Syria, where there are significant Shiite communities, and in the latter case, the Shiite community is represented at the state level by the government of the Syrian President Bashar al-Assad. Like Al Qaida, the "Islamic State" has cells in many countries and carries out terrorist attacks around the world. According to 2016, it is the leader in the number of attacks and deaths. On its account in that year, 1,932 victims and 1132 terrorist attacks in at least 15 countries (Belgium, Georgia, Yemen, Indonesia, Iraq, Jordan, Lebanon, Malaysia, Germany, the Philippines, the Russian Federation, Saudi Arabia, Syria, Tunisia, Turkey), and its network covers at least 32 states. The total number of its victims is tens of thousands. In particular, in 2015, during the fighting of the "Islamic State" with the governments of Iraq, Yemen and Syria in 2015, more than 27,000 people were killed [4, c. 51; 5, p. 73]. 
Thus, a network structure, an extensive system of funding (both from public and private sponsors, and through criminal activity, asymmetric and irregular strategies involving the means of a small war (partisan, sabotage, terrorist actions) - all of this makes transnational terrorism a powerful factor in destabilization of world situation. In addition to a direct terrorist threat, the main danger of the existence of such organizations is that they have all the resources and opportunities to qualify for the status of the state. Transnational networking actors ignore and neutralize the norms of national and international law, reject the existing political order and seek to destroy, disintegrate existing states, create their own entities in their territories. These political entities have their own systems of institutions, the power apparatus, the dominant totalitarian ideology, legal and financial systems. The economy of such quasi-holders does not depend entirely on financial flows by the sponsors of terrorism, but is also capable of autonomous financing through the control of the resource themselves, in particular oil and other minerals, the organization and control of drug trafficking, the taking of hostages for the purpose of extortion, trafficking in persons or the replenishment of their own demographic resources. All this allows maintaining power, introducing own government and providing grounds for further expansion and seizure of new territories. Prior to the organized resistance by regional and international coalitions, successful attempts were made to create alternative quasi-state entities by such organizations as Boko Haram, which controlled vast territories in northern Nigeria, the "Islamic State" that seized the entire provinces in Iraq and Syria, The Taliban, which actually seized power in Afghanistan from 1994 to 1996, now controls Waziristan.

The ideology of Islamist fundamentalism finds support of very large sections of the population in the poorest states and countries in which the traditional structure of society has survived. Islamists act as a force capable of mobilizing people to confront a corrupt and ineffective government, or to combine rumored interpersonal and tribal quarrels among the population. The mentioned organizations are groups of ultra-conservative Salafite direction, which adhere to common doctrinal-ideological principles. The basis of their work is the idea of restoring Islam in its original form, fighting secularism in all its manifestations, overthrowing secular governments in Muslim countries, establishing a Sharia law-governed system, and fighting the West as a hostile Islamic civilization, which in aggregate actually means close to a totalitarian socio-political system regime that excludes the principle of primacy of human rights and freedoms, tolerance and pluralism.

The ideological foundations of Islamist fundamentalism can be seen from the Hamas ideology, which was established in 1987 as the main force for the struggle against Israel for the liberation of the Palestinian lands. The document, known as the "Hamas Charter", contains a direct call for jihad against all those who encroach on Muslims sacred to the land of Palestine. In Art. 15 "Charter" it is said that "the day that enemies usurp part of Moslem land, Jihad becomes the individual duty of every Moslem. In face of the Jews' usurpation of Palestine, it is compulsory that the banner of Jihad be raised. To do this requires the diffusion of Islamic consciousness among the masses, both on the regional, Arab and Islamic levels. It is necessary to instill the spirit of Jihad in the heart of the nation so that they would confront the enemies and join the ranks of the fighters" [6].

It emphasizes the need to involve the widest sections of the population, in particular the intelligentsia, in jihad in order to transform the mass consciousness through cultural institutions, educational institutions, media, political, religious, and cultural leaders so that every Arab, Muslim, Palestinian gets up to fight against invaders, interventionists, which are understood as the Jewish population of Israel, and the West and Christians in general. Particular attention is paid to the system of education of young people, since even school programs need to be modified in such a way that "to cleanse it of the traces of ideological invasion that affected it as a result of the orientalists and missionaries who infiltrated the region following the defeat of the Crusaders..." [6].

As we see, the focus is not even on direct armed resistance, but on ideological instruments of influence on the widest strata of the population in order to mobilize the masses, to strengthen the Islamic identity and to impose extreme nationalism and fundamentalism. And the leading role in these processes is given to religious upbringing and confrontation: "It is necessary to instill in the minds of 
the Moslem generations that the Palestinian problem is a religious problem, and should be dealt with on this basis" [6].

\section{CONCLUSIONS}

Thus, the politicization of religion is a global trend of the present. Ethnic confessional differences are used by interested forces as a powerful source of incitement to interethnic, interreligious and interstate hostility. Violence on a religious basis is a universal destructive phenomenon and is one of the most intense forms of confrontation. Such conflicts do not subsist for a long time, accompanied by great sacrifices, by virtue of their nature - primarily among the civilian population, and greatly destabilizing the socio-political space.

One of the most important components of the problem is transnational terrorism, the danger of which is determined by its transboundary, network and irregular nature. It is not only a powerful disintegration and destabilizing factor, but also it is a threat to the existence of states, their legitimacy, unbalancing national and international systems to create their own, alternative model of world order and cultural environment.

\section{REFERENCES}

[1] Conflict Barometer 2017: disputes non-violent crises violent crises limited wars wars, 26. Heidelberg Institute for International Conflict Research, Heidelberg, 2018. Available at: https://hiik.de/conflictbarometer/current-version/?lang=en

[2] Flash Report: Report of OHCHR mission to Bangladesh. Interviews with Rohingyas fleeing from Myanmar since 9 October 2016. United Nations Human Rights Office of the High Commissioner. 3 February 2017. Available at: http://www.ohchr.org/Documents/Countries/MM/FlashReport3Feb2017.pdf

[3] Global Terrorism Index 2015. The Institute for Economics and Peace, 2015. Available at: http://economicsandpeace.org/wp-content/uploads/2015/11/2015-Global-Terrorism-Index-Report.pdf

[4] Global Terrorism Index 2016. The Institute for Economics and Peace, 2016. Available at: http://economicsandpeace.org/wp-content/uploads/2016/11/Global-Terrorism-Index-2016.2.pdf

[5] Global Terrorism Index 2017. The Institute for Economics and Peace, 2017. Available at: http://visionofhumanity.org/app/uploads/2017/11/Global-Terrorism-Index-2017.pdf

[6] Hamas Covenant 1988. The Avalon Project. Documents in Law, History and Diplomacy. Yale Law School. Lillian Goldman Law Library. Available at: http://avalon.law.yale.edu/20th_century/hamas.asp

[7] Huntington S. The Age of Muslim Wars. Newsweek, 2002. Available at: http://www.novsu.ru/npe/files/ um/1412/bg/shell/arh/istoch/Хантингтон\%20С.\%20Век\%20мусульманских\%20войн.htm (in Russian)

[8] Huntington S. The Clash of Civilizations. "Publishing House ACT", Moscow, 2003. (in Russian)

[9] Petrukhina A.A. The Theory and Practice of Islamism. Bulletin of the Peoples' Friendship University of Russia. Ser. Political Science, 2 (2011), 102-109.

[10] Radical Islamism in sub-Saharan Africa. Available at: http://russiancouncil.ru/extremism-africa (in Russian)

[11] Trends in Global Restrictions on Religion. Pew Research Center, June 23, 2016. Available at: http://www.pewforum.org/2016/06/23/trends-in-global-restrictions-on-religion/ 
Address: Ihor Mykhalskyi, Luhansk Taras Shevchenko National University, 1, Gogol Square, the City of Starobilsk, Luhansk Region, 92703, Ukraine.

E-mail: csaf8385@gmail.com

Received: 25.06.2018; revised: 07.11.2018.

Михальський Ігор. Насилля на релігійному грунті як фактор становлення світового політичного процесу. Журнал Прикарпатського університету імені Василя Стефаника, 5 (3-4) (2018), 25-32.

У статті розкрита роль політичного насилля в сучасному світі крізь призму загострення культурно-релігійних суперечностей. На основі аналізу статистичних даних виявлені тенденції розповсюдження протиборства на релігійному грунті, як-от: дискримінація та утискання прав конфесійних спільнот, етноконфесійні конфлікти, поширення транснаціонального релігійного тероризму. Зроблено висновок, що політизація релігій становить вагомий фактор суспільнополітичної дестабілізації як на регіональному, так і на глобальному рівнях.

Ключові слова: політичне насилля, політичний конфлікт, релігія, цивілізація, етноконфесійні суперечності, ісламізм, транснаціональний тероризм. 